\title{
Dominika Zagrodzka
}

Uniwersytet Śląski, Katowice

\section{Dlaczego jedzenie musi być piękne?}

\begin{abstract}
Abstrakt: W artykule omawiam problem estetyzacji jedzenia. Analizuję dwudziestojednowieczne manifesty napisane przez szefów kuchni, takie jak Open Letter to the Chefs of Tomorrow i Statement on the 'new cookery'. Szczególnie interesuje mnie język, jakiego używają, mówiąc o jedzeniu i gotowaniu. Często jest on podobny do języka używanego do opisu sztuki i procesu twórczego. Przykładowo, jednym z najpopularniejszych terminów jest termin ,interpretacja”, dotyczący zarówno działań kucharzy, jak i jedzących. Podkreśla się, że akt jedzenia powinien być całościowym doświadczeniem i dostarczać emocji zarezerwowanych dla sztuki. Czy rzeczywiście możemy mówić o podobieństwie jedzenia do dzieła sztuki i gotowania do tworzenia? Odwołując się między innymi do rezultatów wstępnych badań, jakie prowadziłam, chcę pokazać, jak koncepcja estetyzacji codzienności Wolfganga Welscha koresponduje z ideą Georga Simmla o estetycznej sile wspólnego stołu. Okazuje się, że chodzi nie tylko o podawanie pięknych dań. Aby osiągnąć satysfakcję estetyczną z posiłku, szczególnie ważne jest, z kim i w jakim otoczeniu jemy. Wspólnota jest czymś nadbudowanym nad jednostkową satysfakcją. Roland Barthes zaznaczał także, że reguły i zakazy obowiązujące podczas jedzenia zostały stworzone, aby ukryć erotyczny, indywidualny aspekt jedzenia.
\end{abstract}

Słowa-klucze: estetyzacja, estetyzacja jedzenia, kultura jedzenia, food studies, kucharz, restauracja

Współcześnie jesteśmy świadkami dynamicznych zmian dokonujących się w kulturze kulinarnej. Dotyczy to zarówno roli kucharza, jak i funkcjonowania restauracji czy jedzenia codziennego. W niniejszym artykule poruszam zagadnienia dotyczące estetyzacji, procesu, który wydaje się szczególnie symptomatyczny dla naszych czasów. Dlaczego chcemy, by nasze jedzenie było piękne? Artykuł jest jedynie przyczynkiem do dalszych rozważań i z pewnością nie obejmuje całości zagadnień związanych z estetyzacją. Zjawisko to uznaję za jeden z elementów współczesnej kultury jedzenia i rozpatruję w szerokim kulturowym kontekście. Pojęcie „estetyzacja” stanowi użyteczne narzędzie, dzięki któremu możemy analizować procesy zachodzące w kulturze. W artykule skupiam się głównie na kulturze zachodnioeuropejskiej i to ją mam na myśli, gdy używam pojęcia „kultura współczesna".

Tekst punktuje pewne tendencje, które możemy dostrzec we współczesnym dyskursie dotyczącym jedzenia, skupiając się głównie na restauracjach uważa- 
nych za ekskluzywne. Tego typu zawężenie może być dyskusyjne, zakładam jednak, że zjawiska zachodzące w najlepszych restauracjach często stają się wzorem dla innych lokali, a także gotowania i podawania posiłków w przestrzeni prywatnej, domowej. Tym samym artykuł wpisuje się w nurt food studies.

Kwestie dotyczące estetyki jedzenia nadal pozostają stosunkowo słabo rozpoznane. Nie można oczywiście zapominać o wpływie takich badaczy, jak Richard Shusterman, twórca pojęcia somaestetyki. W większości refleksja nad estetyzacją w ramach food studies podejmowana jest przez filozofów lub historyków sztuki. Wydaje się istotne, aby w przyszłości, w większym stopniu, włączyć do dyskusji również perspektywę antropologiczną.

W artykule kilka razy odwołuję się do badań, które przeprowadziłam na potrzeby pracy magisterskiej od marca do kwietnia 2015 roku. Osoby, z którymi rozmawiałam, pochodzą z terenu województwa śląskiego. Uwzględniłam trzy grupy wiekowe: do trzydziestego roku życia, od trzydziestego do sześćdziesiątego i po sześćdziesiątym roku życia. Wywiady przeprowadziłam z dwunastoma osobami, po cztery w każdej kategorii wiekowej. Informatorzy byli obojga płci. Badania zostały oparte na stałym kwestionariuszu, który umożliwił porównanie zdobytych danych.

\section{Czym jest estetyzacja?}

Wolfgang Welsch wprowadza pojęcie estetyzacji, które „oznacza, że coś, co jest nie-estetyczne, czynimy czymś estetycznym czy pojmujemy jako coś estetycznego"1. Innymi słowy proces estetyzacji polega na pewnym naddawaniu wartości rzeczom, które ze swej natury rzadko postrzegane są jako estetyczne. Welsch twierdzi, że współcześnie estetyzacji podlega niemal każda sfera życia, od prywatnej — urządzanie mieszkania, strój do publicznej — wygląd ulic, parków, budynków publicznych. Chcemy, żeby wszystko, co nas otacza, było piękne (inna sprawa, że skutkuje to między innymi zakwestionowaniem samej jakości piękna, ponieważ jeśli piękne jest wszystko, to piękne nie jest nic ${ }^{2}$ ). Okazuje się, że ta potrzeba rozciąga się również na jedzenie.

Z kolei Georg Simmel uważa, że „estetyczna stylizacja”3 jest związana ze wspólnotą, która tworzy się podczas posiłku. Pisze o „socjalizacji posiłku”4, która wymaga jego „uestetycznienia”. Proces ten zaczyna się, kiedy normy regulujące

${ }^{1}$ W. Welsch, Estetyka poza estetyka: o nowa postać estetyki, przeł. K. Guczalska, Kraków 2005, s. 119.

${ }^{2}$ Więcej na temat zagrożeń płynących z wszechobecnej estetyzacji: ibidem, s. 121-122.

${ }^{3}$ G. Simmel, Socjologia positku, przeł. M. Łukasiewicz, [w:] idem, Most i drzwi, Warszawa 2006, s. 275.

${ }^{4}$ Ibidem.

Prace Kulturoznawcze 21, 2017, nr 2

(C) for this edition by CNS 
spożywanie posiłków przestają dotyczyć wyłącznie tego, co jemy, ale wiążą się też z tym, jak jemy. Gdy zaczynamy wymagać od posiłku ,satysfakcji estetycznej”, naturalne dla Simmla jest, że zwracamy się ku jedzeniu w grupie, ponieważ satysfakcja estetyczna ,wymaga [...] pewnego nakładu energii, na co stać raczej wspólnotę niż jednostkę, wspólnota jest też właściwszym podmiotem takiej satysfakcji niż jednostka"5. Simmel pokazuje opozycję jednostka-wspólnota, w której jednostkowe zaspokajanie głodu jest zdecydowanie bliższe naturze, podczas gdy jedzenie wspólnotowe, jako wynik procesu socjalizacji, jest bardziej kulturowe. Ale pojawia się tu paradoks. Współcześnie indywidualizacja została bowiem posunięta do granic - osobny talerz, sztućce, stosowne oddalenie od drugiej osoby. Jest to typowe dla sfery kultury. Wydaje się, że nie ma tu wspólnotowości, tego, co dla wielu badaczy i filozofów jest istotą posiłku. Simmel twierdzi jednak, że nad indywidualizmem zostaje nadbudowany element wspólnotowy i to on jest najważniejszy, wprowadzając wartość estetyczną. Tym samym reguły indywidualizujące stają się podstawą reguł wspólnotowych.

Socjalizacja, o której pisze autor, polega na wprowadzeniu coraz bardziej restrykcyjnych reguł dotyczących jedzenia, od ułożenia sztućców przez wygląd talerza po sposoby zachowania się przy stole. Nic nie może zakłócać przyjemności odczuwanej przez osobę jedzącą, przyjemności, która opiera się przede wszystkim na kontakcie z innymi. Osoby, z którymi rozmawiałam w trakcie prowadzenia wstępnych badań, bardzo podkreślały aspekt towarzyski chodzenia do restauracji i, nawet jeśli nie wyrażały tego wprost, było oczywiste, że opisywany przez nich posiłek nie był jedzony w samotności. Także w przestrzeni domowej większość rozmówców spotyka się przy stole z innymi — rodziną lub znajomymi.

Pytanie brzmi więc: czy wymiar estetyczny posiłku to nowa jakość budowana dzięki spędzaniu czasu w grupie, czy raczej przyjemność czerpana z poszczególnych elementów składających się na posiłek, typu wystrój miejsca, w którym jemy, wygląd dań, dekoracje na stole? Wbrew pozorom koncepcje te nie muszą się wykluczać, lecz wręcz przeciwnie — doskonale się uzupełniają. W niniejszym artykule wskazuję na pewne elementy uznawane za ważne z punktu widzenia estetyki, takie jak pięknie wyglądający talerz, ale nie tylko. Wydaje się, że normy obowiązujące podczas gotowania i jedzenia, wymagania stawiane kucharzom, ale i gościom restauracji, moga zostać uznane za odpowiedzialne za Simmlowską „satysfakcję estetyczną”.

\section{Kuchenne manifesty}

W kontekście dokonywanej estetyzacji szczególne znaczenie ma język, jakim mówimy o gotowaniu i jedzeniu. Coraz częściej kucharze porównywani są z artystami, a gotowanie traktowane jest jak sztuka. Warto przyjrzeć się manifestom

\footnotetext{
5 Ibidem.
} 
pisanym przez szefów kuchni. Słowo „manifest” kojarzy się z deklaracją natury artystycznej, z programem dotyczącym tworzonej sztuki. Statement on the 'new cookery' z 2006 roku $^{6}$ oraz Lima Declaration. Open letter to the chefs of tomorrow $^{7}$ z 2011 roku są manifestami napisanymi przez kucharzy. Zostały podpisane przez szefów uznawanych za najlepszych, między innymi René Redzepiego, szefa kopenhaskiej Nomy ${ }^{8}$. Gdy je czytamy, mamy wrażenie, że równie dobrze mogłyby być manifestami stworzonymi na przykład przez artystów plastyków.

Szefowie skupiają się na dążeniu do doskonałości, uważają, że gotowanie i jedzenie może wpływać na ludzi na wiele różnych sposobów. Piszą o wykorzystaniu wszelkich dostępnych środków, po to by dawać ludziom przyjemność, ale i pewnego rodzaju sens (ang. meaning ${ }^{9}$ ). Jedzenie ma służyć tworzeniu tożsamości w obrębie danej kultury, ale także być pomostem, łącznikiem między różnymi kulturami; stół staje się miejscem, przy którym (przynajmniej w teorii) wszelkie podziały zanikają.

Statement on the 'new cookery' składa się z czterech punktów. W punkcie pierwszym szefowie wymieniają najważniejsze zasady gotowania: doskonałość, otwartość na nowe pomysły i uczciwość. Podkreślają, że dzięki współczesnym możliwościom i dostępności produktów mają niepowtarzalną okazję do kulinarnych eksperymentów. Uczciwość (ang. integrity) rozumieją jako wierność przekonaniom i niepodążanie ślepo za nowymi trendami. Punkt drugi łączy się z punktem trzecim. W drugim punkcie kucharze oddają hołd tradycji, piszą, jak wiele zawdzięczają poprzednim pokoleniom szefów kuchni. Uważają, że należy opanować rzemiosło, by móc eksperymentować. Z wprowadzaniem innowacji wiąże się punkt trzeci. Autorzy thumaczą, że nowość dla samej idei nowości nie ma sensu. Nowoczesne technologie nie determinują pracy kucharzy i nie są jej esencją. Dania powinny wzbudzać emocje i angażować intelektualnie, jednak nie tylko przez doskonałość techniczną, lecz także zrozumienie produktu i techniki, akt kreacji. Punkt czwarty jest podsumowaniem i zaakcentowaniem, że jedzenie ma być całościowym doznaniem ${ }^{10}$, co rozwinę w dalszej części tekstu.

Lima Declaration. Open letter to the chefs of tomorrow została podzielona na cztery części. W każdej znajduje się po kilka postulatów, dotyczących kolejno:

${ }^{6}$ Statement on the 'new cookery', https://www.theguardian.com/uk/2006/dec/10/foodanddrink.obsfoodmonthly [dostęp: 13 stycznia 2017].

${ }^{7}$ L. Bianchi, Lima Declaration. Open letter to the chefs of tomorrow, http://www.theworlds50best.com/blog/Events/-lima-declaration-open-letter-to-the-chefs-of-tomorrow.html [dostęp: 13 stycznia 2017].

8 Statement on the 'new cookery' podpisali Ferran Adria, Heston Blumenthal, Thomas Keller, Harold McGee. Lima Declaration została podpisana przez kucharzy: Ferran Adriá, Yukkio Hattori, Massimo Bottura, Michel Bras, René Redzepi, Gastón Acurio, Alex Atala i Dan Barber. Por. Statement on the 'new cookery'; L. Bianchi, op. cit.

9 Statement on the 'new cookery'.

${ }^{10}$ Ibidem. 
związku z naturą, relacji ze społeczeństwem, stosunku do wiedzy, znaczenia konkretnych wartości

W pierwszej części kucharze podkreślają swoją zależność od natury. Uważają, że mają obowiązek nie tylko korzystać z jej darów, lecz także w wyniku przemyślanych wyborów chronić bioróżnorodność. Niejako akcentując zasięg swoich powinności, informują o swojej roli w kulturze i społeczeństwie. Przez gotowanie pokazują i promują tożsamość danego regionu czy kraju, tworzą też „pomost między [różnymi] kulturami”" ${ }^{11}$. Jednocześnie szczególnie ważne jest dla nich oddziaływanie na innych za pomocą jedzenia. Piszą o swoim wpływie zarówno w aspekcie społecznym, jak i ekonomicznym. Zakładają, że mają obowiązek szerzyć zdobytą wiedzę wśród profesjonalistów i amatorów i promować dobre praktyki, związane na przykład z wyborami żywieniowymi. W części dotyczącej wartości, opisują gotowanie jako proces pozwalający im na wyrażenie siebie, piszą o autentyczności, pokorze i pasji ${ }^{12}$.

Przywołuję kulinarne manifesty na początku mojego artykułu nie bez powodu. Są one wyrazem pewnych tendencji, które od dłuższego czasu możemy obserwować we współczesnej kulturze jedzenia. Uznanie kucharzy za osoby o tak wszechstronnym wpływie i znaczeniu dla kultury nie tylko przez nich samych, lecz także przez odwiedzających ich restauracje gości, jest jednym z elementów dokonującego się procesu estetyzacji. W dalszej części tekstu opisuję estetyzację, która dokonuje się na różnych poziomach — postaci i roli kucharza, przestrzeni restauracyjnej, tego, co finalnie pojawia się na stole - jedzenia oraz zakazów i nakazów wiążących się z owym jedzeniem.

\section{Rola kucharza}

Coraz częściej mamy do czynienia z celebrytyzacją kucharzy. Jean-Louis Flandrin, francuski historyk, który zajmuje się historią żywności, w swoich badaniach zwraca uwagę na zmianę, jaka w ciągu wieków dokonała się w zawodzie kucharza. Uważa on, że w XVII wieku kucharze zyskali swego rodzaju autonomię w kwestii tego, co i jak pojawia się na talerzu, wykazywali też znacznie większą pewność siebie. Proces, którego pierwsze oznaki możemy dostrzec w XVII wieku ${ }^{13}$, znajduje swój pełen wyraz w XIX wieku, kiedy na kulinarną scenę wkraczają tacy szefowie, jak Marie-Antoine Carême czy Auguste Escoffier. Współcześnie kucharze są gwiaz-

${ }^{11}$ L. Bianchi, op. cit.

12 Ibidem.

${ }^{13}$ W książkach kucharskich zaznaczają, że to oni mają decydujący głos w kwestii menu i wiedzą najlepiej, jak konkretne danie powinno smakować. Zdarzają się nawet stwierdzenia, w których obśmiewają pewne upodobania amatorów i mimo że podają sposób, jak je zaspokoić, uważają je za co najmniej niewłaściwe. Por. J.-L. Flandrin, Wyróżnienie smaku, przeł. M. Zięba, [w:] Historia życia prywatnego. Od renesansu do oświecenia, red. R. Chartier, Wrocław 1999, s. 308. 
dami porównywalnymi z muzykami, aktorami czy sportowcami. Do zwiększenia roli kucharza przyczyniły się media — wzrost liczby programów kulinarnych, nowe czasopisma dotyczące jedzenia, blogi poświęcone kulinariom. Nie należy jednak zapominać o zmianach dokonujących się w modelu prowadzenia restauracji. Coraz częściej właścicielem jest sam szef kuchni, który wykonuje też funkcje menedżera. Mówi się o kuchni autorskiej, w której kucharz ma wolną rękę w kwestii menu, nie musi uzgadniać go z właścicielem lokalu, a dania sygnuje swoim nazwiskiem ${ }^{14}$.

$\mathrm{Z}$ moich wstępnych badań wynika, że podstawową cechą pożądaną u kucharzy jest kreatywność, zarówno w kwestii smaku, jak i sposobu podawania potraw. W dzisiejszej kulturze kucharze często podnoszeni są do rangi geniuszy, a gotowanie jest sztuką zarezerwowaną dla wybitnych artystów. W manifestach kucharze piszą, że najważniejsza jest dla nich perfekcja, doskonałość. Kilka osób, z którymi rozmawiałam podczas badań, wspomniało o powołaniu do zawodu kucharza, porównywano kucharzy do muzyków, malarzy, rzeźbiarzy. Jeden z profesjonalnych kucharzy stwierdził, że kucharz przypomina malarza, a talerz płótno. Tak jak malarz kładzie farbę na płótnie, tak kucharz układa jedzenie na talerzu, tworząc (wprawdzie ulotne) dzieło sztuki. Współcześnie, zwłaszcza w kontekście kuchni autorskiej, „kucharz staje się demiurgiem” 15 wymyślającym nowe połączenia smaków, zaskakujące formy. Luce Giard pisze o akcie tworzenia również przez amatorów: „wytwarzanie czegoś osobiście, kształtowanie kawałka rzeczywistości, zaznawanie radości demiurgicznej miniaturyzacji, zapewniając sobie jednocześnie uznanie tych, którzy będą go spożywać"16. Kucharz oferuje całościowe doświadczenie, a wizyta w restauracji, w której gotuje, ma się stać niezapomnianym przeżyciem. Côme de Chérisey, jeden z współtwórców przewodnika po restauracjach Gault et Millau, również wyraża taką opinię:

Od wielkiego szefa oczekuję wielkich emocji. Wibrujących, twórczych. Kucharze mają prawo do gorszego dnia, do całkowitego zakwestionowania swojej pracy, do całkowitej zmiany podejścia, do zwątpienia. Są artystami, wolno $\mathrm{im}^{17}$.

${ }^{14}$ Konflikt na linii kucharz-restaurator został ukazany m.in. w filmie Szef Jona Favreau z 2014 roku. Tytułowy szef nie może dowolnie kształtować menu, co powoduje, że od dawna restauracja podaje te same dania. Właściciel lokalu woli sprawdzone, bezpieczne przepisy, dlatego nie zgadza się na, w jego mniemaniu ryzykowne, wprowadzenie do karty nowych dań. Ich relację podsumowuje scena, w której szef kuchni obserwuje podrygującą na sznurkach marionetkę. Co ciekawe, kiedy szef w końcu otwiera własny biznes, nie jest to restauracja, ale food truck.

15 Smakuje, wywiad Łukasza Modelskiego z Grzegorzem Łapanowskim, [w:] Ł. Modelski, Piaty smak. Rozmowy przy jedzeniu, Kraków 2014, s. 174.

${ }^{16}$ L. Giard, Gotować, przeł. K. Thiel-Jańczuk, [w:] M. de Certeau, L. Giard, P. Mayol, Wynaleźć codzienność. Mieszkać, gotować, Kraków 2011, s. 145.

${ }^{17}$ Miejsca smaku, wywiad Łukasza Modelskiego z Côme de Chérisey, [w:] Ł. Modelski, op. cit., s. 274. 
Tym samym idzie o krok dalej i stawia znak równości między kucharzami a $\operatorname{artystami} i^{18}$.

Jednak warto pamiętać, że rodzaj artystycznego zmysłu przydaje się na etapie wymyślania potraw, natomiast podczas codziennej pracy w kuchni trudno mówić o działalności artystycznej, ponieważ gotowanie w restauracji polega na stosunkowo wiernym odtworzeniu pierwotnego wzoru. Czysto techniczne umiejętności, a nie tylko artystyczna impresja, odpowiadają za to, że każde danie jest wykonane według tych samych standardów.

Co ciekawe, większość osób, z którymi rozmawiałam stwierdziła, że nie interesuje ich oglądanie procesu gotowania, a restauracje z otwartą kuchnią często oferują nieprzyjemne zapachy i nie zawsze zachęcający obraz gotujących kucharzy. Ponieważ estetyzacja nie dotyczy tylko potraw, lecz także otoczenia, w którym spożywamy posiłek, istotne jest, by było ono czyste i atrakcyjne. Kilka osób podczas badań, wspomniało o tajemnicy, sekretności pracy kucharza, który niczym alchemik w laboratorium musi mieć spokój i odpowiednią przestrzeń do pracy.

Kolejną kwestią związaną z estetyką jest więc niechęć do oglądania procesu. Liczy się głównie ostateczny efekt. Proces gotowania często nie jest widowiskowy, ponieważ wykonuje go wiele osób (jeśli mówimy o codziennym wydawaniu posiłków w restauracji, a nie jednorazowym pokazie). Proces może być rozrywką, jeśli to osobny pokaz lub jest połączony z elementem rywalizacji, tak jak w programach telewizyjnych. Samo gotowanie w restauracyjnej kuchni rzadko bywa widowiskowe, a dla osób niewtajemniczonych może sprawiać wrażenie wręcz niechlujnego.

\section{Estetyzacja jedzącego}

Precyzyjnie zaprojektowane menu oraz restauracyjne otoczenie zakładają, że do restauracji przyjdzie bardzo konkretny gość. Gość, który będzie miał określoną wiedzę i bagaż doświadczeń, by móc prawidłowo zinterpretować poszczególne elementy restauracyjnego doświadczenia. W filmie dokumentalnym Foodies. The culinary jet set jeden z mężczyzn, który jest restauracyjnym krytykiem, mówi, że ludzie nie rozumieją, że jedzenie nie jest tylko fizyczną, zmysłową przyjemnością. Jedzenie ma być także przyjemnością natury intelektualnej. $Z$ jednej strony,

18 Zaskakujące, jak często oprócz konotacji związanych ze sztuką pojawiają się w dyskursie dotyczącym kulinariów aspekty religijne. Za przykład niech posłuży artykuł z magazynu „The Guardian”, w którym mowa jest o zamknięciu jednej z najlepszych restauracji na świecie — kopenhaskiej Nomy. Ostatnia kolacja przed zamknięciem lokalu porównywana jest do Ostatniej Wieczerzy, jednocześnie wywołując skojarzenia religijne i artystyczne. Artykułowi towarzyszy zdjęcie załogi Nomy, stylizowane na obraz Leonarda da Vinci. Zob. L. Abend, René Redzepi on Noma 's last supper — and what comes next, https://www.theguardian.com/lifeandstyle/2017/jan/15/noma-last-supper-rene-redzepi [dostęp: 13 stycznia 2017]. 
po to by odczytać intencje szefa kuchni, z drugiej, by ocenić jego umiejętności techniczne i nowatorskość potrawy. W dyskursie pojawia się termin „interpretacja" stosowany zarówno w odniesieniu do szefów kuchni, jak i gości restauracji. Kucharze tworzą dania, które są interpretacją, na przykład dań uznawanych za tradycyjne, natomiast jedzący ma poprawnie zinterpretować finalny efekt ich działań.

Co ciekawe, estetyzacja nie ogranicza się tylko do przestrzeni publicznej. Estetyzujemy też na własne potrzeby, dla osób nam bliskich, nawet jeśli nikt nie ma szansy zobaczyć finalnego efektu naszych działań. Przekonanie, że to, co jemy, powinno być piękne, jest przez nas głęboko zinternalizowane.

$\mathrm{Z}$ badań przeprowadzonych przez naukowców wynika, że, wbrew pozorom, nawet osoby uznające się za smakoszy nie odwiedzają restauracji bardzo często, na przykład kilka razy w tygodniu. Isabelle de Solier, która prowadziła badania wśród grupy foodies ${ }^{19}$ z Australii, zauważa, że entuzjaści jedzenia nie chodzą do restauracji częściej niż raz na kilka miesięcy. Skupiają się na własnoręcznym przygotowywaniu wysokojakościowych posiłków w domu. Według badaczki, gotując, niejako „zarabiają” na późniejszą przyjemność jedzenia w restauracji bez wyrzutów sumienia i unikają oskarżeń o konsumpcjonizm. To też skuteczna „,strategia maksymalizacji [odroczonej] przyjemności" ${ }^{20}$. Z kolei badania przeprowadzone przez Alana Warde’a i Lydię Martens wśród osób niebędących foodies dowodzą, że ,jedząc poza domem, mają skłonność do jedzenia ponad miarę i więcej niż zwykle. Było to jednak akceptowane, jako że jedzenie poza domem stanowiło niemal dla wszystkich specjalne wydarzenie" 21 . Z wstępnych badań, które prowadziłam, także wynika, że wyjście do restauracji jest uważane za wyjątkową sytuację, często zakładającą poczynienie odpowiednich przygotowań, takich jak dobranie odpowiedniego stroju. Restauracja staje się przestrzenią podobną do galerii sztuki, służącą do zapoznania się z twórczością danego artysty — kucharza.

\section{Jedzenie jako całościowe doświadczenie}

Jak wspomniałam, podawane jedzenie ma być komunikatem nadawanym przez kucharza i odczytywanym przez jedzącego. Ma informować między innymi o kulinarnej filozofii gotującego. Nierzadko jest to komunikat, który musi być

19 Przez foodies rozumiem tutaj, za de Solier i innymi badaczami, współczesnych smakoszy. Podstawową cechą foodies jest ich zainteresowanie już nie tylko kuchnią wysoką, lecz także kuchniami etnicznymi, street food itp.

${ }^{20}$ I. de Solier, Making the Self in a Material World. Food and Moralities of Consumption, „Cultural Studies Review” 2013, nr 1 (19), s. 18.

${ }^{21}$ L. Martens, A. Warde, Miłe spotkania przy stole, [w:] Socjologia codzienności, red. P. Sztompka, M. Bogunia-Borowska, Kraków 2008, s. 373. 
dodatkowo objaśniony — kelner opowiada wówczas o pochodzeniu składników lub instruuje, w jaki sposób należy zjeść daną potrawę. W Statement on the 'new cookery' czytamy, że „gotowanie może wpływać na ludzi, a jedzenie przekazywać wiadomość od kucharza"22.

W serialu dokumentalnym sieci Netflix Chef's Table, który prezentuje sylwetki najlepszych kucharzy, każdy z nich mówi o jedzeniu jako komunikacie (ang. message). Szefowie wspominają o nauce rzemiosła od mistrzów, ale podkreślają też, że dopiero w momencie otwarcia własnej restauracji mogą tworzyć w pełni. Własny lokal oznacza odejście od kopiowania, naśladowania tego, czego się nauczyli. W jednej ze scen Niki Nakayama, znana i ceniona szefowa kuchni, opowiada o pracy w restauracji sushi. Mówi o powtarzalności wykonywanych czynności i o tym, że nie było tam miejsca na prawdziwą sztukę, którą tworzy teraz, we własnej restauracji.

W najlepszych restauracjach podstawową formą podawania posiłku są kolacje degustacyjne. To rodzaj pokazu umiejętności szefa kuchni i przekrój przez wszystkie dania serwowane w lokalu. Jest to dobra opcja dla osób, które nie mają możliwości przychodzenia do restauracji regularnie i próbowania, podczas kolejnych wizyt, różnych dań. Dlatego daje się im szansę spróbowania większości dań w trakcie jednego wieczoru. Porcje są malutkie, ale dań jest więcej niż przy standardowym obiedzie czy kolacji, od kilkunastu do kilkudziesięciu.

Podejście do gotowania we współczesnych restauracjach jest efektem zmian, jakie dokonały się w kuchni francuskiej w latach siedemdziesiątych XX wieku. Henri Gault i Christian Millau, twórcy przewodnika po restauracjach Gault \& Millau, w 1973 roku spisali dziesięć punktów charakteryzujących „nową kuchnię” (fr. nouvelle cuisine). Zgodnie z zaproponowanymi przez nich założeniami kucharze powinni skoncentrować się na produkcie wysokiej jakości, pozyskując go z lokalnych źródeł. Potrawy miały być lekkie, bez ciężkich sosów, a kucharz cały czas powinien zaskakiwać restauracyjnych gości nowymi połączeniami smakowymi. W nouvelle cuisine ważny był też aspekt estetyczny. Kucharz musiał zaprojektować wygląd talerza ${ }^{23}$.

Szefowie kuchni zdają się zwracać szczególną uwagę na traktowanie jedzenia jako niepowtarzalnego doświadczenia. W Statement on the 'new cookery' zostały zapisane symptomatyczne słowa: „Akt jedzenia angażuje wszystkie zmysły, tak samo jak umysł. Przygotowywanie i serwowanie jedzenia jest być może najbardziej kompleksową i wszechstronną ze sztuk widowiskowych" ${ }^{24}$. Spożywanie dań ma być całościowym doświadczeniem. Przyjemność estetyczna płynie nie tylko z efektów wizualnych, lecz także słuchowych (jedzenie, które „wydaje od-

22 Statement on the 'new cookery' [tłumaczenie własne].

23 A. Drouard, Chefs, gourmets and gourmands. French Cuisine in the 19th and 20th Centuries, [w:] Food. The history of taste, red. P. Freedman, Londyn 2007, s. 295.

24 Statement on the 'new cookery' [tłumaczenie własne]. 
głosy" podczas spożywania, na przykład chrupie), węchowych (zatrzymywanie aromatu, na przykład pod szklanym kloszem, który zostaje podnoszony już przy stoliku, by gość mógł w pełni poczuć zapach potrawy), dotykowych (łączenie różnych struktur w potrawie: miękkie/twarde, gładkie/chropowate, ale też dobór odpowiednich naczyń). Dobrym przykładem będzie restauracja szefa Paco Roncero, Sublimotion, na Ibizie. Posiłek w Sublimotion trwa około trzech godzin i jest połączeniem jedzenia, sztuki i technologii. Goście siedzący przy jednym długim stole są świadkami multimedialnego spektaklu, a wyświetlane na ścianach-ekranach i stole wizualizacje mają potęgować doznania płynące z jedzenia (przykładowo, gdy na stole pojawiają się owoce morza, na ścianach wyświetlany jest podwodny świat, a z głośników dobiega dźwięk między innymi fal) $)^{25}$.

Jednak jako konsumenci chcemy jak najdalej od owej natury — przypominania nam o organicznym pochodzeniu spożywanych produktów - uciec. Warto zwrócić uwagę, że elementy natury pokazywane na ekranach w Sublimotion zostały „przefiltrowane” przez kulturę i podane w formie uważanej przez gości za atrakcyjną rozrywkę. Jedną z możliwych przyczyn dokonywania procesu estetyzacji jest uciekanie od biologii. Można tu wyodrębnić dwa poziomy. Na pierwszym poziomie ucieczka od aspektów biologicznych dokonuje się za pomocą wyglądu jedzenia na talerzu. Marta Bucholc w artykule „Kto nie pracuje, ten niechaj nie je”. O socjologicznych interpretacjach jedzenia pisze:

Najoczywistszym zabiegiem mistyfikującym jedzenie jest oczywiście odebranie mu charakteru jedzenia, niejako zaprzeczenie, że to, co się dzieje, jest jedzeniem, a to, co jemy, to substancje pochodzenia $[\ldots]$ naturalnego poddawane wewnątrz naszego organizmu procesom pozakulturowej obróbki ${ }^{26}$.

Jedzenie ma nie wyglądać jak jedzenie, co ułatwia układanie go w przemyślną kompozycję. Próbujemy odsunąć od siebie naturalność jedzenia, zwracając nasz wzrok wyłącznie w stronę kultury ${ }^{27}$. Roland Barthes także pisał o kuchni „dekoracyjnej”, skupionej na uciekaniu od biologii. Wzrok jest tu zmysłem wyróżnionym. Ważnym we współczesnej kulturze zjawiskiem jest nierzadkie zastępowa-

25 http://www.sublimotionibiza.com [dostęp: 3 stycznia 2017].

${ }^{26} \mathrm{M}$. Bucholc, ,, Kto nie pracuje, ten niechaj nie je”. O socjologicznych interpretacjach jedzenia, [w:] Pongo, t. 5. Antropologia praktyk kulinarnych. Szkice, red. R. Chymkowski, A. Jaroszuk, M. Mostek, Warszawa 2012, s. 21.

${ }^{27}$ Napięcie między naturalnością jedzenia a jego ukulturalnianiem doskonale pokazuje serial Hannibal. Tytułowy bohater, znany też z książkowego oryginału, Hannibal Lecter, praktykuje kanibalizm. To, jak gotuje, pokazywane jest jednak w sposób wręcz przeestetyzowany - elegancko ubrany mężczyzna, w lśniącej czystością kuchni, smaży i piecze, przygotowując wyszukane dania, a w tle brzmi muzyka klasyczna. Odbiorca otrzymuje wiele zbliżeń prezentujących przygotowywanie poszczególnych elementów dania. Składniki są następnie układane w niezwykłe kompozycje. Estetyzacja dokonywana w serialu ma służyć wzbudzeniu w widzu ambiwalentnych uczuć — z jednej strony dania i sposób ich przygotowania wyglądają bardzo apetycznie, z drugiej, ponieważ wiemy, skąd pochodzi mięso użyte do potraw, czujemy do nich wstręt (i niechęć do siebie, że uznaliśmy je za apetyczne). Co ciekawe, oba te uczucia są z poziomu kultury, nie natury.

Prace Kulturoznawcze 21, 2017, nr 2

(C) for this edition by CNS 
nie patrzeniem rzeczywistego aktu konsumpcji. Zarówno media internetowe (na przykład Instagram), jak i tradycyjne (albumowe książki kucharskie, czasopisma) zakładają, że ich odbiorca potrzebuje przede wszystkim ładnych obrazków. Przyjemność estetyczna wyczerpuje się wtedy w spojrzeniu, coraz częściej zresztą rozmaici naukowcy donoszą, że patrząc na smakowitą potrawę, jesteśmy w stanie zniwelować rzeczywisty apetyt. Michael Pollan w pracy Cooked pisze o paradoksie z tym związanym (w oryginale Cooking Paradox). Otóż według autora Amerykanie gotują coraz mniej, natomiast coraz więcej czasu poświęcają na oglądanie programów kulinarnych czy czytanie książek kucharskich. Pollan twierdzi, że wynika to z faktu, że brakuje im czasu lub energii na samodzielne gotowanie, ale nie potrafią całkowicie zrezygnować z tej czynności, dlatego oglądają ją na przykład na ekranach telewizora. Autor uznaje gotowanie za coś, za czym tęsknimy, a oglądanie tej czynności za substytut gotowania. Według Pollana fascynuje nas podglądanie procesu własnoręcznego wytwarzania (oczywiście procesu estetyzowanego na potrzeby mediów) ${ }^{28}$.

Według Barthes’a w przemyślanym ozdabianiu potraw chodzi o

złagodzenie lub nawet zamaskowanie pierwotnej natury składników, surowości mięsa lub szorstkości skorupiaków. Danie chłopskie dopuszcza się, w wyjątkowych sytuacjach (sztuka mięsa $\mathrm{w}$ rosole - tradycyjny posiłek rodzinny) jako wiejską fantazję zblazowanych mieszczuchów ${ }^{29}$.

Barthes również podkreśla dwoistość zabiegów ozdabiania potraw:

$\mathrm{z}$ jednej strony wymykanie się naturze w jakby barokowym uniesieniu (szpikowanie cytryny krewetkami, zabarwienie kurczaka na różowo, podanie ciepłych grejpfrutów), z drugiej zaś próba jej odtworzenia za pomocą dziwacznych zabiegów (rozłożenie bezowych grzybów i liści ostrokrzewu na bożonarodzeniowych stroikach, umieszczenie głów raków wokół wyrafinowanego beszamelu, który zakrywa ich odwłoki) ${ }^{30}$.

Warto pamiętać, że współcześnie owo maskowanie pierwotnej natury jest ułatwione także przez produkty spożywcze, które kupujemy. Przepisy kulinarne z XIX wieku zawierały zwykle instrukcję, jak pozbawić życia zwierzę, które miało zostać podane na obiad ${ }^{31}$. Dzisiaj kupujemy gotowe kawałki mięsa, nierzadko wymagające jedynie obróbki termicznej. Reklamy produktów odzwierzęcych skupiają się na pokazaniu samego produktu, ewentualnie szczęśliwych zwierząt. Kwestie etyki hodowli są podnoszone między innymi przez wegetarian, ale dla przeciętnego konsumenta to drugorzędny temat.

${ }^{28}$ M. Pollan, Cooked, London 2013, s. 4-5.

${ }^{29}$ R. Barthes, Kuchnia dekoracyjna, przeł. A. Dziadek, [w:] idem, Mitologie, Warszawa 2000, s. 165 .

${ }^{30}$ Ibidem, s. 166.

${ }^{31} \mathrm{~S}$. Bednarek, O niektórych osobliwościach przepisów kulinarnych w ksiązkach kucharskich XIX wieku, [w:] Oczywisty urok biesiadowania, red. P. Kowalski, Wrocław 1998, s. 65. 
Wiąże się to także z tematem, o którym jedynie wspomnę, gdyż jego rozwinięcie to materiał na kolejny artykuł. Pokarmy wzbudzające w nas wstręt, obrzydliwe, niepiękne znajdują się na drugim biegunie poruszanych tu zagadnień. Nierzadko odmawiamy ich estetyzowania, ponieważ sam kontakt z danym produktem wywołuje odrzucenie. To, co spożywamy, jest przecież związane z czymś tak oczywistym, jak uznanie pokarmów za jadalne. Wyznaczenie granicy indywidualnie (osoby starsze często nie uznają za jadalne owoców morza), ale i kulturowo (we współczesnej polskiej kulturze obce jest na przykład jedzenie robaków, normalne w kulturach azjatyckich) tworzy rozdział między sferą natury i kultury. Wszystko, co uznamy za jadalne, staje się w pewien sposób bezpieczne, oswojone, stoi po stronie kultury. Z niejadalnym wiąże się lęk, nierzadko wynikający z niewiedzy, który sytuuje tego typu produkty po stronie natury ${ }^{32}$.

Bucholc wspomina, że odwróceniu uwagi od natury sprzyjają również rozmowy przy stole, zwykle dotyczące tematów neutralnych, niedotyczących na przykład wydalania czy innych czynności fizjologicznych związanych z jedzeniem ${ }^{33}$. Rozmowa musi dotyczyć tematów uważanych za lekkie i przyjemne, nie może być zbyt poważna, żeby nie przysłonić samego aktu jedzenia, nazywanego przez Simmla „,bazą”, na której opiera się przyjemność wynikająca ze wspólnotowego spożywania posiłku ${ }^{34}$.

Estetyzacja dokonuje się więc także na tym poziomie. Wbrew pozorom swoboda przy stole ograniczana jest wieloma respektowanymi społecznie i zinternalizowanymi normami, które precyzyjnie określają, co wolno, a co jest surowo wzbronione. Ich przestrzeganie ma wpływać na, wspominaną przez Simmla, ,satysfakcję estetyczną", całościowy wymiar posiłku.

Lothar Kolmer pisze o zanikaniu „surowej rytualizacji” związanej z jedzeniem, przejawiającej się, między innymi, w niezmiennej kolejności spożywanych podczas uczt dań, ściśle określonych porach jedzenia, wyznaczonych momentach, w których trzeba milczeć, i tych, podczas których można rozmawiać. Przy tej okazji autor przywołuje dziewiętnastowieczne dinner party, które były wydawane głównie przez osoby aspirujące do zajęcia wyższej pozycji w społecznej hierarchii i nie dość, że wiązały się z rygorystycznie przestrzeganą etykietą, to oznaczały również ogromne koszty, ponoszone przez gospodarza ${ }^{35}$. Rytualizacja czynności związanych z jedzeniem nie zanikła całkowicie. Współczesnym odpo-

32 Warto wspomnieć, że jedzenie pełni przede wszystkim funkcję tworzenia określonej tożsamości, co podkreśla też Lothar Kolmer. Chodzi tu zarówno o tożsamość jednostki, budowaną aktami spożywania, ale też przygotowywania czy podawania określonych potraw, jak i tożsamość grupową, tożsamość danej społeczności, która znajduje swój wyraz w obowiązującej kulturze jedzenia. Zob. L. Kolmer, Przyjmowanie i wykluczanie, [w:] F.-T. Gottwald, L. Kolmer, Jedzenie. Rytuaty i magia, Warszawa 2009, s. 256.

${ }^{33}$ M. Bucholc, op. cit., s. 22.

34 G. Simmel, op. cit., s. 280.

${ }^{35}$ L. Kolmer, Wprowadzenie, [w:] F.-T. Gottwald, L. Kolmer, op. cit., s. 12-13. 
wiednikiem dinner party byłaby właśnie wizyta w restauracji i rządzące nią zasady, które wbrew pozorom nadal są dość ściśle określone ${ }^{36}$. Reguły zachowania w lokalu wyznacza przede wszystkim savoir-vivre. Sam termin pochodzi z języka francuskiego, od savoir — wiedzieć i vivre — życie. Savoir-vivre oznaczałby więc „znajomość życia” rozumianą jako maniery, obycie, umiejętność zachowania się w każdej sytuacji. Zgodnie z koncepcją Norberta Eliasa przez wieki normy dotyczące zachowania przy stole coraz bardziej się zaostrzają. Zwykle były inne dla każdej warstwy społecznej. Warstwy niższe naśladowały warstwy wyższe, które z kolei stosowały coraz bardziej restrykcyjne normy, żeby podkreślić swoją wyjątkową pozycję. Elias uważa, że następuje proces interioryzacji norm społecznych (które służą głównie stłumieniu popędów) przez jednostkę. Być może to właśnie z powodu uwewnętrznienia norm wiele osób uznaje pewne zasady za całkowicie naturalne ${ }^{37}$. Jak pisze Elias:

Owe przymusy wewnętrzne, funkcje ustawicznej retrospekcji i przewidywania, wykształcane w jednostce od dzieciństwa odpowiednio do jej uwikłania w długie łańcuchy interakcji, przybierają po części postać świadomego samoopanowania, po części formę automatycznie funkcjonujących nawyków; przyczyniają się one do bardziej równomiernego thumienia, do ustawicznego hamowania, do dokładniejszego regulowania manifestacji popędów i emocji, według zróżnicowanego, odpowiadającego sytuacji społecznej schematu ${ }^{38}$.

Zasady są uznawane za naturalne, jak powiedziałby Claude Lévi-Strauss, w wyniku unaturalnienia kultury.

Ich nieznajomość czy też ryzyko nieznajomości przyczynia się do określania wizyty w restauracji jako obwarowanej restrykcyjnymi regułami. Będąc w restauracji, musimy dostosować się do wymagań grupy, którą tworzą zarówno osoby siedzące z nami przy stoliku, jak i wszyscy obecni w restauracji, od kelnerów po innych gości. Kolmer pisze, że jeśli jednostka okaże się niekompetentna, podważy swoją przynależność do grupy. Autor przytacza przykłady z eleganckich restauracji, w których wiele osób nie radzi sobie z obsługą szczypców do skorupiaków ${ }^{39}$.

Drugi poziom, uciekania od natury w stronę kultury, dotyczy opisywanego procesu indywidualizacji nakrycia stołu. Zmiany, które przez wieki dokonały się w wyglądzie stołu i rodzaju zastawy, to znakomity przykład na postępującą indywidualizację. Przeszliśmy długą drogę od jedzenia z jednej misy wspólną łyżką do zindywidualizowanego nakrycia. Warto zauważyć, że „własny talerz, kieli-

${ }^{36}$ Nie oznacza to oczywiście, że w domu nie ma żadnych zasad czy reguł. Obowiązującą normą jest na przykład kolejność podawania potraw czy reguły zachowania przy stole. Są to zasady mniej restrykcyjne niż w restauracji, ale nadal przestrzegane i uznawane za ważne.

${ }^{37}$ Dla Eliasa ,popędy, namiętności, które nie manifestują się już teraz bezpośrednio w stosunkach między ludźmi, często nie mniej gwałtownie walczą obecnie w jednostce", co stanowić może poważny problem dla jednostki. Por. idem, Przemiany obyczajów w cywilizacji Zachodu, przeł. T. Zabłudowski, Warszawa 1980, s. 384.

38 Ibidem, s. 385.

${ }^{39}$ L. Kolmer, Wprowadzenie, s. 16. 
szek, nóż, łyżka i widelec budują w istocie rzeczy niewidzialne przegrody między współbiesiadnikami" ${ }^{40}$. Dodatkowo,

przy stole obowiązują ścisłe obyczaje. Każdy powinien ukryć dolną połowę swojego ciała pod drewnianym blatem i połami obrusa. Ukazujemy innym tylko wyprostowaną górną część ciała, z obydwoma nadgarstkami złożonymi swobodnie po obu stronach nakrycia ${ }^{41}$.

Według Barthes’a, siedzenie przy stoliku z drugą osobą nie jest wcale aż tak bezpieczne, jak mogłoby się wydawać. Barthes pisze:

Wokół stołu czuć jakiś nieokreślony popęd do prześwietlania: wypatrujemy (śledzimy?) w innych działania pożywienia; próbujemy uchwycić, w jaki sposób ciało pracuje od wewnątrz. Niczym sadyści rozkoszujący się wzrostem niepokoju na twarzy partnerki obserwujemy zmiany w ciele, które się dobrze pożywia ${ }^{42}$.

Jedzenie miałoby więc w sobie pierwiastek erotyczny, intymny, a reguły dotyczące zachowania przy stole służyłyby zakryciu owej fizjologii jedzenia.

\section{Paradoks talerza}

Warto zauważyć, że talerz stawiany przed gościem restauracji zostaje uznany za swoiste i jedyne w swoim rodzaju dzieło sztuki. Jak już wspominałam, codzienna praca w kuchni ma raczej wymiar rzemieślniczej powtarzalności niż tworzenia rzeczy nietypowych. Kucharze mają tworzyć według danego wzoru, wszystkie talerze pozostają więc takie same. To szef kuchni, często w porozumieniu z resztą zespołu, decyduje o układzie poszczególnych elementów dania na talerzu, a fakt, że każdy wydany talerz wygląda tak samo jak poprzedni, świadczy o niezwykle wysokim poziomie restauracji. Jednocześnie każdy restauracyjny gość ma mieć poczucie, że znajdujący się na jego stole talerz jest wyjątkowy i został przygotowany specjalnie dla niego.

Simmel pisze, że talerz podkreśla indywidualizm, jest „cząstką, wydzieloną z całości na użytek jednego biesiadnika i odmówioną innym"43. Talerz stanowi swego rodzaju granicę między jedzącymi. Jednak indywidualizm nakrycia zostaje przezwyciężony przez jednakowość talerzy na stole, wszyscy jedzą z takich samych naczyń. Ta koncepcja sprawdza się w przestrzeni domowej, w restauracji naczynia o wiele bardziej różnią się w zależności od podawanej potrawy. Warto zauważyć, że kuchnia autorska, o której wspomniałam, zakłada podawanie dań w przeznaczonych do tego naczyniach, głównie dlatego że potrawa jest w całości realizacją pomysłu szefa kuchni i wszelkie elementy kompozycji smakowej i wizualnej powinny

40 J.-L. Flandrin, op. cit., s. 278.

${ }^{41}$ L. Giard, op. cit., s. 181.

${ }^{42}$ R. Barthes, Czytanie Brillat-Savarina, [w:] idem, Lektury, przeł. K. Kłosiński, M.P. Markowski, E. Wieleżyńska, Warszawa 2001, s. 182.

${ }^{43}$ G. Simmel, op. cit., s. 274. 
znaleźć się na talerzu; na przykład nie podaje się osobno sałatki, ponieważ jeśli jest ona dodatkiem do dania, zostaje w nie wkomponowana na talerzu. Podobnie dzieje się w większości restauracji, jednak często się zdarza, że różne elementy dodatkowe podawane są osobno, nierzadko w sposób nieprzemyślany.

Z kwestią estetyki podawania potraw wiąże się też problem nadawania daniom nazw. Nazwa, według Luce Giard, „ma za zadanie zakryć i udramatyzować, a więc zaintrygować i zbulwersować, klient ma zamówić, ślepo zawierzając nieznanym słowom, które go całkowicie usatysfakcjonują"44. Podobne stanowisko prezentuje polska badaczka Anna Dąbrowska: „Nazwy potraw powinny swym brzmieniem skłaniać do skosztowania i rozkoszowania się dobrym jadłem. Samo wsłuchiwanie się w ich melodię stanowić może nie lada przyjemność" 45 . Według tej autorki nazwa pełni kilka funkcji, między innymi służy odróżnieniu dania od innych dań, pokazuje, z czego i jak jest ono przyrządzone, a dodatkowo zwiększa walory dania, na przykład przez zastosowanie nazwy obcojęzycznej lub poetyckiej ${ }^{46}$. Moi rozmówcy jednak jednogłośnie stwierdzali, że zawoalowane nazwy potraw, z których nie wynika wprost, jakie danie pod nimi się kryje, tylko przeszkadzają w dokonaniu wyboru i nierzadko wymagają konsultacji z kelnerem. Tym samym nazwa wprowadza gości w zakłopotanie i podkreśla ich niekompetencję. Ponadto nazwa skonfrontowana $\mathrm{z}$ otrzymanym daniem może okazać się jedynie rodzajem pięknej zasłony rzeczy zupełnie zwyczajnej. W wielu nowoczesnych lokalach, zamiast nazywać dania, wymienia się po prostu składniki, aby gość był zaskoczony tym, co później znajdzie się na jego talerzu. Dzięki znajomości poszczególnych elementów możemy wyobrazić sobie smaki, ale ich połączenia i faktury składników często okazują się inne od oczekiwanych.

\section{Podsumowanie}

Proces estetyzacji dotyczy wielu obszarów współczesnej kultury kulinarnej. Uwidacznia się zwłaszcza w dyskursie, gdy mówimy o kucharzach jako artystach, gotowaniu jako procesie twórczym, a jedzeniu jako obcowaniu z dziełem sztuki. Anna Wieczorkiewicz w Apetycie turysty stwierdza: „To nieprawda, że w restauracjach sprzedaje się posiłki, a w biurach podróży wycieczki; oba rodzaje instytucji oferują całościowe doznania" ${ }^{\prime 7}$. Wydaje się, że to właśnie jest i będzie najważniejsze zadanie kucharzy - zagwarantować osobie jedzącej całościowe doświadczenie, oparte na oddziaływaniu na wszystkie zmysły. Niezwykle istotny pozostaje

${ }^{44}$ L. Giard, op. cit., s. 203.

45 A. Dąbrowska, O językowym zachowaniu się przy stole. Dlaczego upiększamy nazwy potraw, [w:] Oczywisty urok biesiadowania, s. 252.

46 Ibidem, s. 249.

47 A. Wieczorkiewicz, Apetyt turysty. O doświadczaniu świata w podróży, Kraków 2008, s. 293. 
zmysł wzroku. Nierzadko ma on znaczenie decydujące przy wyborze i ocenie potrawy, a „spożycie może się wyczerpać w samym tylko spojrzeniu" ${ }^{48}$. Z estetyką wiąże się też umiejętność rozmowy o jedzeniu, która dopiero zaczyna być istotna w naszej kulturze. Ciągle wzrastająca liczba blogów, nie tylko oferujących przepisy, lecz także opisujących dania restauracyjne, mnóstwo programów telewizyjnych, nowe magazyny dotyczące jedzenia sprawiają, że spożywanie posiłków przestaje być uznawane za coś trywialnego, a mówienie o jedzeniu za banał.

$\mathrm{Z}$ perspektywy antropologicznej szczególnie istotny wydaje się konflikt między naturą i kulturą. Napięcia pojawiające się między tymi dwoma biegunami znajdują wyraz w relacji indywidualizacja-wspólnotowość, które realizuje się między innymi podczas posiłku.

Z pewnością pozostaje wiele zagadnień, które wymagają doprecyzowania. Niezwykle ważna problematyka dotycząca jedzenia poza domem i opozycji przestrzeń publiczna-przestrzeń prywatna warta jest dalszych badań. Podobnie jak kwestia słownictwa, jakim się posługujemy, próbując opisać jedzenie — zwłaszcza szczegółowa analiza recenzji pisanych przez krytyków kulinarnych mogłaby przynieść odpowiedzi na niektóre z pytań badawczych antropologii.

\section{Why food must be beautiful?}

\section{Abstract}

In my article I discuss the problem of the anesthetization of food. I analyzed the 21 st century manifestos written by the chefs, including Open Letter to the Chefs of Tomorrow and Statement on the »new cookery «. I am particularly interested in the language they use talking about food and cooking. It is often similar to the language which is used to describe the work of art and the creative process. For example, the most popular term is 'interpretation' concerning the activities of cooks and eaters. It is emphasized that the act of eating is supposed to be holistic experience and should provide feelings reserved for art. But how much can you actually talk about the similarity of food to the pieces of art and about the similarity of cooking to creating something? Referring to the results of the preliminary research that I conducted, I want to show how to combine Wolfgang Welsch's concepts about everyday aesthetisation and Georg Simmel's ideas about the aesthetic power of a community table. It turns out that it is not just about to serve beautiful plates. To be satisfied with the meal it is also important who we eat with and in what setting. The community is something appearing over the individual satisfaction. Roland Barthes admitted that the rules and prohibitions are designed also to cover the erotic aspects of feasting.

Keywords: aesthetization, aesthetization of food, food culture, food studies, cook, restaurant

${ }^{48}$ R. Barthes, Kuchnia dekoracyjna, s. 166. 


\section{Bibliografia}

Abend L., René Redzepi on Noma's last supper — and what comes next, https://www.theguardian. com/lifeandstyle/2017/jan/15/noma-last-supper-rene-redzepi [dostęp: 13 stycznia 2017].

Barthes R., Czytanie Brillat-Savarina, [w:] idem, Lektury, przeł. K. Kłosiński, M.P. Markowski, E. Wieleżyńska, Warszawa 2001.

Barthes R., Kuchnia dekoracyjna, [w:] idem, Mitologie, przeł. A. Dziadek, Warszawa 2000.

Bednarek S., O niektórych osobliwościach przepisów kulinarnych w ksiązkach kucharskich XIX wieku, [w:] Oczywisty urok biesiadowania, red. P. Kowalski, Wrocław 1998.

Dąbrowska A., O językowym zachowaniu się przy stole. Dlaczego upiększamy nazwy potraw, [w:] Oczywisty urok biesiadowania, red. P. Kowalski, Wrocław 1998.

Bianchi L., Lima Declaration. Open letter to the chefs of tomorrow, http://www.theworlds50best.com/ blog/Events/-lima-declaration-open-letter-to-the-chefs-of-tomorrow.html [dostęp: 13 stycznia 2017].

Bucholc M., „Kto nie pracuje, ten niechaj nie je”. O socjologicznych interpretacjach jedzenia, [w:] Pongo, t. 5. Antropologia praktyk kulinarnych. Szkice, red. R. Chymkowski, A. Jaroszuk, M. Mostek, Warszawa 2012.

Drouard A., Chefs, gourmets and gourmands. French Cuisine in the 19th and 20th Centuries, [w:] Food. The history of taste, red. P. Freedman, London 2007.

Elias N., Przemiany obyczajów w cywilizacji Zachodu, Warszawa 1980.

Flandrin J.-L., Wyróżnienie smaku, [w:] Historia życia prywatnego. Od renesansu do oświecenia, red. R. Chartier, przeł. M. Zięba, K. Osińska-Boska, M. Cebo-Foniok, Wrocław 1999.

Giard L., Gotować, [w:] M. de Certeau, L. Giard, P. Mayol, Wynaleźć codzienność. Mieszkać, gotować, przeł. K. Thiel-Jańczuk, Kraków 2011.

Gottwald F.-T., Kolmer L., Jedzenie. Rytuaty i magia, Warszawa 2009.

Martens L., Warde A., Miłe spotkania przy stole, [w:] Socjologia codzienności, red. P. Sztompka, M. Bogunia-Borowska, Kraków 2008.

Miejsca smaku, wywiad Łukasza Modelskiego z Côme de Chérisey; Smakuje, wywiad Łukasza Modelskiego z Grzegorzem Łapanowskim, [w:] Ł. Modelski, Piaty smak. Rozmowy przy jedzeniu, Kraków 2014.

Pollan M., Cooked, London 2013.

Simmel G., Socjologia positku, [w:] idem, Most i drzwi, przeł. M. Łukasiewicz, Warszawa 2006.

Solier I. de, Making the Self in a Material World. Food and Moralities of Consumption, „Cultural Studies Review" 2013, nr 1 (19).

Statement on the 'new cookery', https://www.theguardian.com/uk/2006/dec/10/foodanddrink. obsfoodmonthly [dostęp: 13 stycznia 2017].

Welsch W., Estetyka poza estetyką: o nowa postać estetyki, przeł. K. Guczalska, Kraków 2005.

Wieczorkiewicz A., Apetyt turysty. O doświadczaniu świata w podróży, Kraków 2008.

http://www.sublimotionibiza.com [dostęp: 3 stycznia 2017].

Prace Kulturoznawcze 21, 2017, nr 2

(c) for this edition by CNS 